\title{
Regional variations of organophosphorus flame retardants - Fingerprint of large river basin estuaries/deltas in Europe compared with China ${ }^{\text {tr }}$
}

\author{
Hendrik Wolschke ${ }^{\text {a, b, * }}$, Roxana Sühring ${ }^{c}$, Riccardo Massei ${ }^{\text {d, e }}$, Jianhui Tang ${ }^{\text {, }}$ \\ Ralf Ebinghaus ${ }^{a}$ \\ ${ }^{\text {a }}$ Helmholtz-Zentrum Geesthacht, Institute of Coastal Research, Germany \\ ${ }^{\mathrm{b}}$ Leuphana Universität Lüneburg, Germany \\ ${ }^{\mathrm{c}}$ The Centre for Environment, Fisheries \& Aquaculture Science (Cefas), UK \\ ${ }^{\mathrm{d}}$ Helmholtz Center for Environmental Research, Germany \\ ${ }^{\mathrm{e}} \mathrm{RWTH}$ Aachen University, Germany \\ ${ }^{\mathrm{f}}$ Key Laboratory of Coastal Environmental Processes and Ecological Remediation, Yantai Institute of Coastal Zone Research, CAS, Yantai 264003, China
}

\section{A R T I C L E I N F O}

\section{Article history:}

Received 8 September 2017

Received in revised form

7 January 2018

Accepted 17 January 2018

\begin{abstract}
A B S T R A C T
This study reports the occurrence and distribution of organophosphorus flame retardants and plasticizer (OPEs) in sediments of eight large river basin estuaries and deltas across Europe. A robust and sensitive OPE analysis method was developed through the application of an in-cell clean-up in an accelerated solvent extraction and the use of an GC-MSMS System for instrumental analyses. OPEs were detected in all sediment samples with sum concentrations of up to $181 \mathrm{ng} \mathrm{g}^{-1} \mathrm{dw}$. A fingerprinting method was used to identify river specific pattern to compare river systems. The estuaries and deltas were chosen to have a conglomerate print of the whole river. The results are showing very similar OPE patterns across Europe with minor differences driven by local industrial input. The European estuary concentrations and patterns were compared with OPEs detected in the Xiaoquing River in China, as an example for a region with other production, usage and legislative regulations. The Chinese fingerprint differed significant from the overall European pattern.
\end{abstract}

๑) 2018 Elsevier Ltd. All rights reserved.

\section{Introduction}

Sediments provide important services in the estuarine ecosystem. They are habitats for a variety of species that form the basis for local food-webs (Kennish, 1992). Due to this importance and their place at the "start" of the food-web, sediments have often been discussed as starting point of bioaccumulation and magnification of lipophilic contaminants (Ernst et al., 1988; Kennish, 1992). Mid-to non-polar compounds absorb to particles and are deposited on the sea floor (Ernst et al., 1988) where they can be immobilized and stored or enter the food-web. Therefore, sediments can be function as sink but also as a secondary source for contaminants

\footnotetext{
This paper has been recommended for acceptance by Dr. Harmon Sarah Michele.

* Corresponding author. Helmholtz-Zentrum Geesthacht, Institute of Coastal Research, Germany.

E-mail address: hendrik.wolschke@hzg.de (H. Wolschke).
}

\section{(Laane et al., 2013).}

Organophosphate esters (OPEs) are widely used as flame retardant and plasticizers in a variety of products such as electronic equipment, furniture, textiles, isolation material and wires (Muir, 1984). Additionally, they are used in up to $15 \%$ (by weight) as additives in hydraulic fluids, lubricants and antifoaming agents (Hartmann et al., 2004). With the restriction of polybrominated diphenyethers (PBDEs), organophosphate based flame retardants have become a focus for the polymer industry (van der Veen and Boer, 2012). A result of that is a strong increasing of the production and consumption of OPEs as flame retardants on the global market (van der Veen and Boer, 2012; Wang et al., 2010).

OPEs are primarily used additively in products, which mean they are not chemical bound to the product, which aids the leachout into the environment (Staaf and Östman, 2005). Risk assessments of several, especially chlorinated, OPEs have shown a potential for carcinogenic effects, acute toxicity as well as high environmental persistence (Reemtsma et al., 2008; Waaijers and 
Parsons, 2016; Wang et al., 2015). OPEs primarily enter the aquatic environment through atmospheric deposition and leaching from waste water treatment, from where they can be transported into marine areas (Bollmann et al., 2012; Wolschke et al., 2015). Some OPEs travel in part attached to particles (Wolschke et al., 2016; Sühring et al., 2016b) which allows for sinking and accumulating in sediments (Giulivo et al., 2017). Based on their physical-chemical properties, especially the longer chained and the chlorinated OPEs have the potential to accumulate in sediments (Zhang et al., 2016; Sühring et al., 2016b). However, the occurrence and distribution of organophosphate flame retardants in sediments is still not sufficiently understood. The presented study focused on the accumulation of OPE sediments from seven major European estuaries. Estuaries were chosen as study areas because they represent a conglomeration over the whole river and allow fingerprinting of the river contamination profile. At the same time estuaries are very specific unique ecosystems which have to handle the fluctuating salinity gradients with moving turbidity and nutrient conditions (Martin and Brun-Cottan, 1988).

In this study, we compared eight European river basins to identify contamination levels and river specific patterns across Europe. Europe has relatively limited production of OPEs and has strict environmental legislations that prevent the production or use of particularly hazardous OPEs (European Commission, 2014). To compare the contamination with a different catchment area and legislative regulation, sediments samples from an estuary in north east China were analyzed.

\section{Materials and methods}

\subsection{Sample collection}

29 surface sediment samples were collected from eight large estuaries and delta in Europe. The samples were collected from 2013 to 2015 by stainless steel grab sampler from ship or from shore at low tide. The sediment samples were stored at $-20^{\circ} \mathrm{C}$ prior to analysis. Sampling sites are shown in Fig. 1. From the Xiaoquing River in China 5 samples were collected in 2014.

A full list of the sampling sites is presented in the Supplementary Information (Si) Table S1.

\subsection{Sample preparation}

The extraction and clean-up were adapted from a method

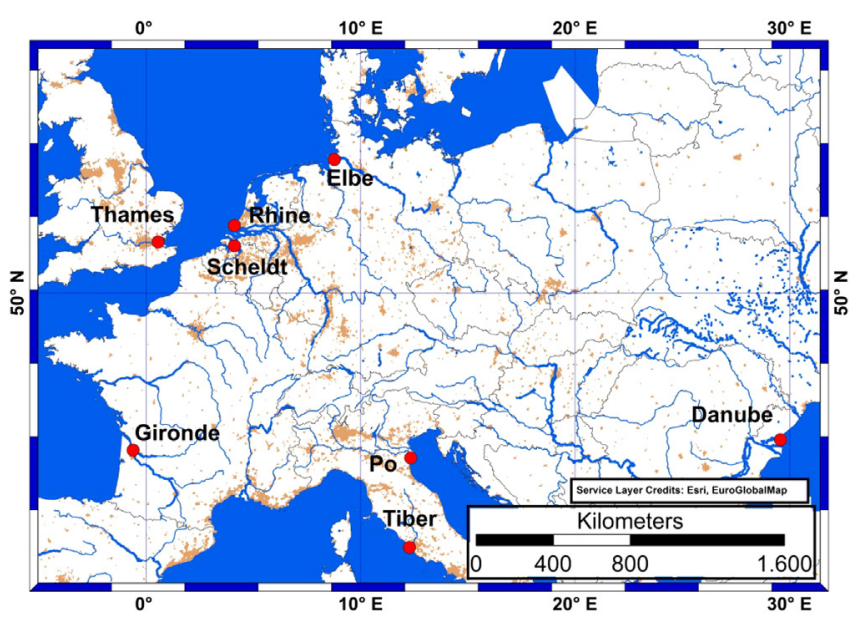

Fig. 1. European sampling sites. presented by Sühring et al. (2016a). Larger pieces ( $>2 \mathrm{~mm}$ ) were removed by hand from the sediment samples. The samples were homogenized with anhydrous sodium sulfate $\left(\mathrm{Na}_{2} \mathrm{SO}_{4}\right)$ using an agate mortar. The samples were extracted using accelerated solvent extraction (Thermo Fisher ASE-350) with an in-cell clean-up (Sühring et al., 2016a). $22 \mathrm{~mL}$ stainless steel ASE cells were filled with $7 \mathrm{~g} \mathrm{10 \%}$ deactivated silica gel, $2 \mathrm{~g}$ activated Copper and 5-15 g dried sediment. All samples were spiked with mass labelled surrogate standards TCEP-d12, TBP-d27, TPhP-d15.

The cells were extracted sequentially in two fractions. The first fraction was extraction with following parameters: 2 cycles, hexane as solvent, pressure (nitrogen): 9 bar, temperature: $100^{\circ} \mathrm{C}$, pressure: 120 bar, heat: $5 \mathrm{~min}$, static (2x): $8 \mathrm{~min}$, flush: $100 \%$, purge: $60 \mathrm{~s}$. The second faction was extracted using the same conditions with 90:10 Dichloromethane:Acetone as solvent. This second fraction (containing the OPEs), was reduced in volume and subjected to a further clean-up by a $2.5 \mathrm{~g} 10 \%$ water deactivated silica gel column. For elution $20 \mathrm{~mL}$ of acetone/DCM $(1: 1 \mathrm{v} / \mathrm{v})$ were used and the sample reduced to a volume of $150 \mu \mathrm{L}$ under a gentle stream of heated nitrogen $\left(40^{\circ} \mathrm{C}\right)$. Finally, $500 \mathrm{pg}$ (absolute) ${ }^{13} \mathrm{C}$ PCB-141 and ${ }^{13}$ C-PCB-208 were added as injection standards to each sample. Recoveries of deuterated standards, extraction efficiency, blanks and reproducibility were tested with and without matrix, during method validation. All samples were analyzed in duplicates.

Separate sample aliquots were dried to constant weight (at $105^{\circ} \mathrm{C}$ ) for the gravimetrical determination of water content as well as the subsequent analysis of total organic carbon (TOC). TOC was measured using a LECO RC612 multiphase carbon/hydrogen/moisture determinator combustion method at $400{ }^{\circ} \mathrm{C}$.

\subsection{Instrumental analysis}

The samples were analyzed on a GC-MS/MS system (Agilent 7010) in electron impact ionization mode (EI) equipped with two DB-35MS columns $(15 \mathrm{~m} \times 0.25 \mathrm{~mm}$ i.d. $\times 0.25 \mu \mathrm{m}$ film thickness, J\&W Scientific) connected to a purge unit for backflush after each run. The injector was operated in pulsed-splitless mode (injection pulse 20 psi for $2 \mathrm{~min}$ ) with an inlet temperature program as follows: $60^{\circ} \mathrm{C}$ for $0.1 \mathrm{~min}$ and $300^{\circ} \mathrm{C} \mathrm{min}^{-1}$ until $300^{\circ} \mathrm{C}$ and held for a final $20 \mathrm{~min}$. The GC oven program was as follows: initial $60^{\circ} \mathrm{C}$ for $4 \mathrm{~min}, 25^{\circ} \mathrm{C} \mathrm{min}^{-1}$ until $100^{\circ} \mathrm{C}, 7^{\circ} \mathrm{C} \mathrm{min}^{-1}$ until $310^{\circ} \mathrm{C}$ and held for $1 \mathrm{~min}$. The backflush was performed at $310 \mathrm{~min}$ with a flow of $1.5 \mathrm{~mL} \mathrm{~min}^{-1}$ at the first column for $5 \mathrm{~min}$. The temperature of the MS transfer line was held at $280^{\circ} \mathrm{C}$. The ion source and quadrupole temperatures were $150^{\circ} \mathrm{C}$.

A list of the mass transitions used for quantitative analysis are provided in Table S2.

\subsection{Quality assurance and quality control $(Q A / Q C)$}

Because of the widespread presence of OPEs in a variety of laboratory equipment, the use of rubber and plastic materials was avoided to minimize blank contamination during the transport, storage and treatment of the samples. All glassware was cleaned prior to use by a laboratory dishwasher, baked at $250^{\circ} \mathrm{C}$ and rinsed with acetone. $\mathrm{Na}_{2} \mathrm{SO}_{4}$ was cleaned by Soxhlet extraction with DCM for $12 \mathrm{~h}$ and baked at $450^{\circ} \mathrm{C}$. Blank samples were analyzed with every batch of 10 samples. Detected blanks were at least one order of magnitude below the measured concentrations for all of the target compounds. Absolute blank values ranged from $0.1 \pm 0.02 \mathrm{ng}$ for TiBP to $0.5 \pm 0.15 \mathrm{ng}$ for TCPP for the whole method. Method detection limits (MDLs) were derived from either the mean blank values plus three times the standard deviation or at a signal-tonoise ratio of $3(S / N=3)$, whichever approach yielded the higher 
value. Based on a sample amount of $10 \mathrm{~g}$, MDLs ranged from $37 \mathrm{pg} \mathrm{g}^{-1}$ for TiBP to $250 \mathrm{pg} \mathrm{g}^{-1}$ for TCPP. The average recoveries of the surrogates were $76 \pm 18 \%$ for TCEP-d $12,56 \pm 18 \%$ for TnBP-d27, and $74 \pm 16 \%$ for TPhP-d15. All reported concentrations were corrected for blanks and recoveries.

\section{Results and discussion}

\subsection{Analytical method}

The use of a GC-MS/MS system with a (mid-column) backflush system compared to classic GC-MS systems provided a strong increase of condition stability, while reducing matrix effects. After each run the first half part of the column was flushed backwards with high temperature carrier gas to eliminate matrix debris on the column. These advantages compared with the GC-MS/MS-System lead to a more robust analysis with increased sensitivity and selectivity for the analyses of OPEs in environmental samples (Wolschke et al., 2016). Due to the wide range of physical-chemical properties, instability of compounds and blank contamination, using classic GC-MS, it has been challenging to develop an extraction and cleanup method for complex sediment matrices that reduces the matrix effects enough while not impairing the analytes. With the describe advantage of the GC-MSMS method with midcolumn backflush the clean-up process can be simplified.

\subsection{Environmental occurrence and fate}

OPEs were detected in all analyzed sediment samples. The sum concentrations for the European river sediments ranged from $2.5 \mathrm{ng} \mathrm{g}^{-1}$ dry weight ( $\left.\mathrm{dw}\right)$ at an up-stream position in the river Gironde to $181 \mathrm{ng} \mathrm{g}^{-1} \mathrm{dw}$ in the Belgian river Scheldt. In general, the absolute concentrations were highly variable between the individual rivers. Individual concentrations are provided in Table S3. The concentrations are comparable to other studies from Europe. In Greece sediment concentrations in the Evrotas river between 10.5 and $248 \mathrm{ng} \mathrm{g}^{-1} \mathrm{dw}$ were reported (Giulivo et al., 2017). In the Adige river, Italy OPE concentrations in sediments ranged from 11.5 to $549 \mathrm{ng} \mathrm{g}^{-1} \mathrm{dw}$ and in Slovenia in the Sava river basin from 0.31 to $310 \mathrm{ng} \mathrm{g}^{-1} \mathrm{dw}$ (Giulivo et al., 2017). Interestingly, Brandsma et al. (2015) reported lower OPE concentrations in the river Scheldt river $\left(<0.1-19.6 \mathrm{ng} \mathrm{g}^{-1} \mathrm{dw}\right)$ compared to this study. A possible explanation could be that the OPE concentrations have increased over the years, as the samples from Brandsma et al. (2015) were collected in 2008, compared to 2014 for this study. But local differences in accumulation capacities and discharge patterns could also be a reason for the differences in detected concentrations. To ensure comparability between the sampling sites, the contamination levels and patterns in this study are therefore being discussed normalized for TOC (Fig. 2). The results indicated that the river Scheldt with OPEs concentration up to $18 \mu \mathrm{g} \mathrm{g}^{-1} \mathrm{TOC}$ is the most contaminated river for OPEs in Europe (Fig. 2), followed by the Rhine, Thames and Po. The rivers Elbe, Danube, Tiber and Gironde displayed overall lower OPEs contaminations (Fig. 2). These differences in concentrations was expected, the catchment area of the rivers Scheldt (Antwerp), Rhine (Rotterdam, Ruhr area) and Thames (London) are highly populated and strongly influenced by industry. An interesting exemption to this observation were the high OPEs concentrations ( $17 \mu \mathrm{g} \mathrm{g}^{-1} \mathrm{TOC}$ ) at a sampling station in the river Gironde near the city of Blaye (Gironde 2 in Fig. 2), suggesting that there might be local sources for OPEs in that area.

In all samples, the chlorinated tris(2-chloroethyl) phosphate (TCPP) was the dominating (highest concentrated and detection frequency) compound with a contribution to the sum of OPEs up to $70 \%$ (average 63\%). The high contributions of TCPP were congruent

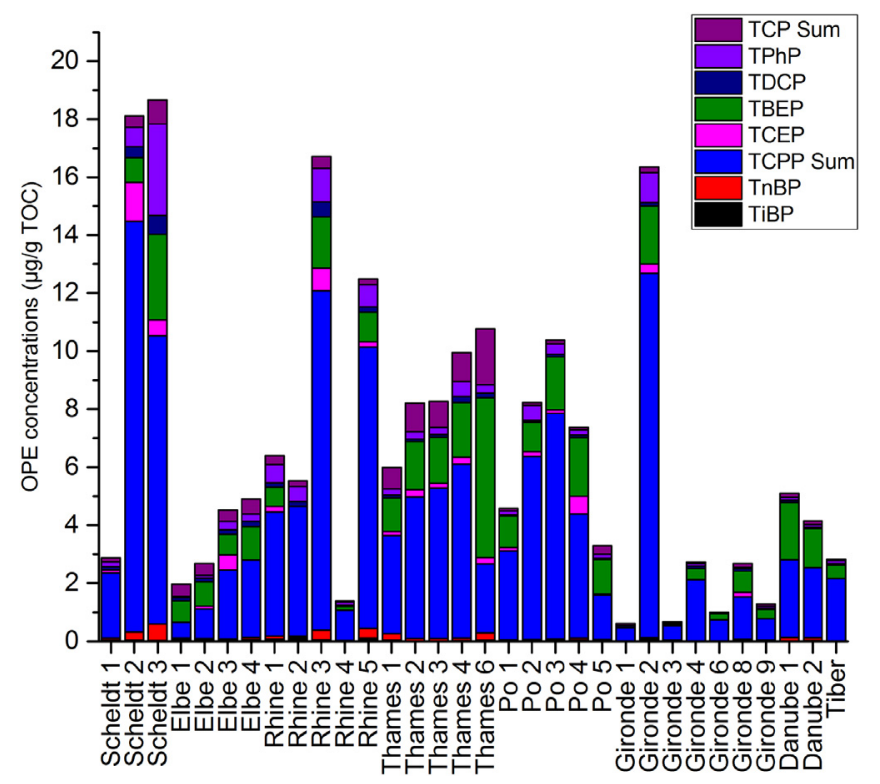

Fig. 2. Individual sediment concentrations along the estuaries in $n g g^{-1}$ TOC dry weight.

with findings reported in other matrices from Europe (Malarvannan et al., 2015; Möller et al., 2011; Regnery and Püttmann, 2009; Wolschke et al., 2015, 2016). The second highest concentrated and prevalent compound was Tris(2-butoxyethyl) phosphate (TBEP) with an average contribution of $18 \%$. However, compared to TCPP, TBEP showed a higher variability of contributions to sum OPEs in different rivers. In Elbe and Gironde TBEP had the highest contributions to the OPEs contamination pattern with up to $30 \%$, whereas its contributions in the river Scheldt were lower $(0-15 \%)$. The reason is not clear, and it can indicate a higher input of TBEP in this river catchments but a specific usage or production is not known in this area. Another OPE with river specific contamination pattern was Tri-cresly-phosphate (TCP) - in the rivers Elbe and Thames its contribution was comparably high with around $10 \%$ of total compared to the average contribution in other rivers of only $3 \%$. These findings indicated that for many OPEs, the contamination patterns are location specific, forming an individual fingerprint.

To compare the contamination patterns from a use area (Europe) and a production area (China), five samples from the Xiaoquing River, Shandong, China were analyzed. The catchment area of the river encompasses industrial areas around the cities Weifang, Zibo and Jinan. The results of the estuare from Xiaoquing River are match able with investigations of the connected Bohai Sea published by Zhong et al., 2018, which implicate a representative set for the region.

The OPE patterns in the Xiaoquing were noticeably different compared to the patterns found in European rivers (Fig. 3). The major component was TCEP (46\%), a component that is restricted in Europe (European Commission, 2014). Consequently, the contributions of TCEP in Europe are significantly lower $(p<0.01)$. At the same time, the major component in Europe, TCPP, only contributed around $20 \%$ to the OPE pattern in China (Fig. 3). TCPP is the main replacement for TCEP (World Health Organization, 1998). The differences in patterns between Europe and China highlight the effectiveness of restrictions of TCEP, but also the problem of "regrettable substitution", since the overall use of OPEs has not declined but the pattern has merely shifted to other OPE components. An interesting similarity between the OPE patterns in China and Europe were the high contribution of TCP which were also 


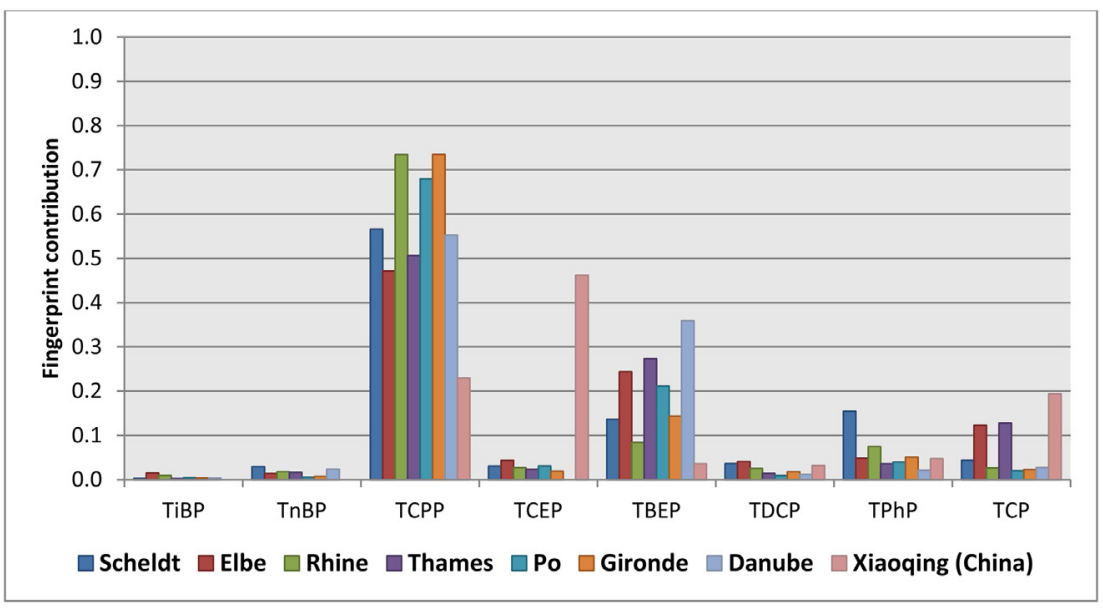

Fig. 3. Fingerprint of different estuaries/deltas.

Table 1

Pearson correlations of fingerprint analyses.

\begin{tabular}{|c|c|c|c|c|c|c|c|c|}
\hline & & Elbe & Rhine & Thames & Po & Gironde & Danube & Xiaoqing (China) \\
\hline \multirow[t]{2}{*}{ Scheldt } & Pearson corr & 0.910 & 0.998 & 0.894 & 0.976 & 0.993 & 0.861 & 0.265 \\
\hline & Sig. & $1.67 \mathrm{E}-03$ & $1.09 \mathrm{E}-08$ & $2.71 \mathrm{E}-03$ & $3.28 \mathrm{E}-05$ & $6.38 \mathrm{E}-07$ & 0.00596 & 0.524 \\
\hline \multirow[t]{2}{*}{ Elbe } & Pearson corr & 1 & 0.908 & 0.997 & 0.966 & 0.941 & 0.969 & 0.218 \\
\hline & Sig. & & $1.78 \mathrm{E}-03$ & $2.44 \mathrm{E}-08$ & 8.77E-05 & $4.78 \mathrm{E}-04$ & $6.74 \mathrm{E}-05$ & 0.603 \\
\hline \multirow[t]{2}{*}{ Rhine } & Pearson corr & & 1 & 0.892 & 0.976 & 0.995 & 0.859 & 0.244 \\
\hline & Sig. & & & $2.84 \mathrm{E}-03$ & 3.39E-05 & 2.97E-07 & 0.00621 & 0.559 \\
\hline \multirow[t]{2}{*}{ Thames } & Pearson corr & & & 1 & 0.958 & 0.928 & 0.974 & 0.191 \\
\hline & Sig. & & & & $1.74 \mathrm{E}-04$ & $8.51 \mathrm{E}-04$ & $3.98 \mathrm{E}-05$ & 0.650 \\
\hline \multirow[t]{2}{*}{ Po } & Pearson corr & & & & 1 & 0.992 & 0.948 & 0.221 \\
\hline & Sig. & & & & & $1.03 \mathrm{E}-06$ & 3.33E-04 & 0.598 \\
\hline \multirow[t]{2}{*}{ Gironde } & Pearson corr & & & & & 1 & 0.905 & 0.229 \\
\hline & Sig. & & & & & & 0.00198 & 0.585 \\
\hline \multirow[t]{2}{*}{ Danube } & Pearson corr & & & & & & 1 & 0.089 \\
\hline & Sig. & & & & & & & 0.832 \\
\hline
\end{tabular}

present in Elbe and Thames.

\subsection{Fingerprint analyses}

To analyze individual contamination "fingerprints" of the different estuaries, a method for the "Fingerprint Analysis of Contaminant Data" (Russell, 2004) by the United States Environmental Protection Agency (EPA) was used. The average concentrations [pg $\mathrm{g}^{-1} \mathrm{dw}$ ] of each river were used to determining the contribution to the sum contamination in the investigation area (i.e. specific estuary):

$\operatorname{con}_{x i}[\%]=\frac{c_{x i}\left[\mathrm{pg} \mathrm{g}^{-1} d w\right]}{\sum_{i=1}^{n} c_{x i}\left[\operatorname{pg~g}^{-1} d w\right]}$

With

$\operatorname{con}_{x}[\%]$ : Contribution in \% of compound $X_{i=1-n}$ to the sum concentration in the investigation area.

$c_{x i}\left[\mathrm{pg} \mathrm{g}^{-1} d w\right]$ : Concentration of compound $X_{i=1-n}$ in $\mathrm{pg} \mathrm{g}^{-1} \mathrm{dw}$.

$d \sum_{x=1}^{n} c_{x}\left[\mathrm{pg} \mathrm{g}^{-1} d w\right]$ : Sum concentration of all compounds $\mathrm{X}$ in the investigation area in $\mathrm{pg} \mathrm{g}^{-1} \mathrm{dw}$.

The resulting contribution of individual substances to the contamination pattern in an investigated area was then used to create a "fingerprint" of the contamination patterns in that area (Fig. 3). For comparison of the different investigation areas, the determined patterns were correlated with each other, using a Pearson correlation analyses (Table 1). As expected, the OPE patterns in European rivers were very similar with Pearson correlation coefficients between 0.86 and 0.99 (Table 1, Fig. 3). Particularly, the Scheldt and Rhine with a similar catchment and in parts water mixing were highly correlated $(r>0.99)$; but high correlations were also found for the Gironde in France and the Po in Italy $(r>0.99)$. The correlation of Po and Gironde are interesting, because of the different catchment areas the Po with highly industrialised areas and the large cities Turin and Milan in contrast to the rural area around Bordeaux. The other "group" was the Elbe estuary in Germany, the Thames in England and the Danube Rumania. These had highly intercorrelated patterns ( $r>0.99$ ), but were slightly less correlated with the Scheldt, Rhine, Gironde and Po patterns $(\mathrm{r}<0.97)$ (Table 1$)$.

The pattern in the Xiaoquing River as an example for China was significantly different from all analyzed European estuaries $(\mathrm{p}<0.01)$ with correlation coefficients between 0.08 (Danube) and 0.27 (Scheldt) (Table 1). The different profile highlighted the differences between production and usage areas, as well as the differences in legislations. The presented study showed that a common market and harmonised regulations generates a comparable fingerprint of contamination and can effectively reduce contamination from specific hazardous compounds such as the chlorinated TCEP in a large area.

\section{Acknowledgments}

The sampling campaigns were organized and supported by the 
following institutions, which we gratefully acknowledge: National Research Center of Milan, Italy; Brunel University, London, UK; University of Bordeaux, Bordeaux, France; International commission for the Protection of the Danube (ICPDR), Vienna, Austria. We especially acknowledge the sampling coordinators: Stefano Polesello, Sara Spedicati and Pierre Labadie. We acknowledge funding by the SOLUTIONS Project supported by the European Union Seventh Framework Programme (FP7-ENV-2013-two-stage Collaborative project) under grant agreement no. 603437.

\section{Appendix A. Supplementary data}

Supplementary data related to this article can be found at https://doi.org/10.1016/j.envpol.2018.01.061.

\section{References}

Bollmann, U.E., Möller, A., Xie, Z., Ebinghaus, R., Einax, J.W., 2012. Occurrence and fate of organophosphorus flame retardants and plasticizers in coastal and marine surface waters. Water Res. 46 (2), 531-538.

Brandsma, S.H., Leonards, P.E.G., Leslie, H.A., de Boer, J., 2015. Tracing organophosphorus and brominated flame retardants and plasticizers in an estuarine food web. Sci. Total Environ. 505, 22-31.

Ernst, W., Boon, J., Weber, K., 1988. Occurrence and fate of organic micropollutants in the north sea. In: Salomons, W. (Ed.), Pollution of the North Sea. An Assessment. Springer-Verlag, Berlin, New York, pp. 285-299.

European Commission, 2014. Commission Directive 2014/79/EU.

Giulivo, M., Capri, E., Kalogianni, E., Milacic, R., Majone, B., Ferrari, F., Eljarrat, E., Barceló, D., 2017. Occurrence of halogenated and organophosphate flame retardants in sediment and fish samples from three European river basins. Sci. Total Environ. 586, 782-791.

Hartmann, P.C., Bürgi, D., Giger, W., 2004. Organophosphate flame retardants and plasticizers in indoor air. Chemosphere 57 (8), 781-787.

Kennish, M.J., 1992. Ecology of Estuaries: Anthropogenic Effects. CRC Press, Boca Raton, Ann Arbor, London, p. 494.

Laane, R., Vethaak, A., Gandrass, J., Vorkamp, K., Köhler, A., Larsen, M., Strand, J. 2013. Chemical contaminants in the Wadden Sea: sources, transport, fate and effects. J. Sea Res. 82, 10-53.

Malarvannan, G., Belpaire, C., Geeraerts, C., Eulaers, I., Neels, H., Covaci, A., 2015. Organophosphorus Flame Retardants in the European Eel in Flanders, Belgium: Occurrence, Fate and Human Health Risk. . (Accessed 29 February 2016).

Martin, J., Brun-Cottan, J., 1988. Estuaries. In: Salomons, W. (Ed.), Pollution of the North Sea. An Assessment. Springer-Verlag, Berlin, New York, pp. 88-99.

Möller, A., Xie, Z., Caba, A., Sturm, R., Ebinghaus, R., 2011. Organophosphorus flame retardants and plasticizers in the atmosphere of the North Sea. Environ. Pollut. 159 (12), 3660-3665.
Muir, D.C.G., 1984. Phosphate esters. In: Atlas, E., Fishbein, L., Giam, C.S., Leonard, J.E., Muir, D.C.G., Powers, M.A., Schoer, J. (Eds.), Anthropogenic Compounds. Springer Berlin Heidelberg, Berlin, Heidelberg, pp. 41-66.

Reemtsma, T., Quintana, J.B., Rodil, R., García-López, M., Rodríguez, I., 2008. Organophosphorus flame retardants and plasticizers in water and air I. Occurrence and fate. Trac. Trends Anal. Chem. 27 (9), 727-737.

Regnery, J., Püttmann, W., 2009. Organophosphorus flame retardants and plasticizers in rain and snow from Middle Germany. Clean. - Soil, Air, Water 37 (4-5), $334-342$

Russell, H. Plumb, 2004. Fingerprint Analysis of Contaminant Data: a Forensic Tool for Evaluating Environmental Contamination (Bibliogov).

Staaf, T., Östman, C., 2005. Organophosphate triesters in indoor environments. J. Environ. Monit. 7 (9), 883-887.

Sühring, R., Busch, F., Fricke, N., Kötke, D., Wolschke, H., Ebinghaus, R., 2016a. Distribution of brominated flame retardants and dechloranes between sediments and benthic fish - a comparison of a freshwater and marine habitat. Sci. Total Environ. 542, 578-585.

Sühring, R., Wolschke, H., Diamond, M.L., Jantunen, L., Scheringer, M., 2016b. Distribution of organophosphate ester flame retardants between gas- and particle phase - model predictions vs. measured data. Environ. Sci. Technol. 50 (13), 6644-6651.

van der Veen, I., Boer, J. de, 2012. Phosphorus flame retardants: properties, production, environmental occurrence, toxicity and analysis. Chemosphere 88 (10), 1119-1153.

Waaijers, S.L., Parsons, J.R., 2016. Biodegradation of brominated and organophosphorus flame retardants. Curr. Opin. Biotechnol. 38, 14-23.

Wang, R., Tang, J., Xie, Z., Mi, W., Chen, Y., Wolschke, H., Tian, C., Pan, X., Luo, Y., Ebinghaus, R., 2015. Occurrence and spatial distribution of organophosphate ester flame retardants and plasticizers in 40 rivers draining into the Bohai Sea, north China. Environ. Pollut. 198, 172-178.

Wang, X., Liu, J., Yin, Y., 2010. The pollution status and research progress on organophosphate ester flame retardants. Prog. Chem. 22 (10), 1983-1992.

Wolschke, H., Sühring, R., Mi, W., Möller, A., Xie, Z., Ebinghaus, R., 2016. Atmospheric occurrence and fate of organophosphorus flame retardants and plasticizer at the German coast. Atmos. Environ. 137, 1-5.

Wolschke, H., Sühring, R., Xie, Z., Ebinghaus, R., 2015. Organophosphorus flame retardants and plasticizers in the aquatic environment: a case study of the Elbe River, Germany. Environ. Pollut. 206, 488-493.

World Health Organization, 1998. Flame Retardants: Tris(chloropropyl) Phosphate and Tris(2-chloroethyl) Phosphate. Environmental Health Criteria 209. World Health Organization, Geneva, p. 106 xix.

Zhang, X., Sühring, R., Serodio, D., Bonnell, M., Sundin, N., Diamond, M.L., 2016. Novel flame retardants: estimating the physical-chemical properties and environmental fate of 94 halogenated and organophosphate PBDE replacements. Chemosphere 144, 2401-2407.

Zhong, M., Wu, H., Mi, W., Li, F., Ji, C., Ebinghaus, R., Tang, J., Xie, Z., 2018. Occurrences and distribution characteristics of organophosphate ester flame retardants and plasticizers in the sediments of the Bohai and Yellow Seas, China. Sci. Total Environ. 615, 1305-1311. https://doi.org/10.1016/ j.scitotenv.2017.09.272. 